\title{
Innovative methodological tool for occupational risk quantification
}

\author{
Haralambie Vochitoiu ${ }^{1,}{ }^{*}$, Camelia Lavinia Unguraș ${ }^{1}$, Olga Miclea $^{2}$, Bogdan Gaita ${ }^{1}$, Ioan \\ Rus $^{1}$, Gabriel Ioan Ilcea ${ }^{1}$, Gabriel Dragos Vasilescu ${ }^{2}$, Nicolae Iliaș ${ }^{1}$, Dan Dumitru Pintilie ${ }^{1}$, \\ and Ciprian Mateiu ${ }^{1}$ \\ ${ }^{1}$ University of Petrosani - Doctoral School, 20 Universitatii street, 332006, Petrosani, Hunedoara \\ county, Romania \\ ${ }^{2}$ National Institute for Research and Development in Mine Safety and Protection to Explosion \\ INSEMEX, 32-34 G-ral Vasile Milea Street, 332047 Petrosani, Romania
}

\begin{abstract}
This paper presents research in the field of estimating and assessing occupational risks, in order to secure the activities carried out in the presence of specific hazards of industrial work systems, and is based on an in-depth knowledge of interdisciplinary notions in various fields related to systems security engineering. The innovative methodological tool highlights a way to quantify the phenomenon of manifestation of hazards specific to work processes that generate occupational risks with impact, both on the human component and at the level of other components specific to work systems, which significantly reduces the inherent subjectivity in assessing the risks caused by the human factor.
\end{abstract}

\section{Introduction}

The mechanism for generating an unwanted event in the work process is based on the following elements of logical inference [1]: the generator of danger specific to the work system and the time horizon at which a certain risky activity takes place; the trigger which, depending on the danger generated, turns a risk into an undesirable event such as an accident at work or an occupational disease; characteristic indication (specific response) regarding human exposure to risk (victim(s) who suffered an accident at work or an occupational disease) [2].

Usually, in a functional work system there are 5 categories of risk factors that depending on the particular and specific way of manifestation, can generate work accidents or occupational diseases (figure 1), respectively [3]:

Category I: Risks caused by work equipment and materials / substances used, respectively: Technical equipment $\left(\mathrm{C}^{\mathrm{I}}{ }_{100}\right)$; Tool / tools $\left(\mathrm{C}_{200}{ }_{200}\right.$; Energy sources that ensure the operation of technical equipment $\left(\mathrm{C}_{300}^{\mathrm{I}}\right)$; Materials / substances used in the work process $\left(\mathrm{C}_{400}^{\mathrm{I}}\right)$; Other risks produced $\left(\mathrm{C}_{500}^{\mathrm{I}}\right)$.

Category II: Risks caused by the work environment: Adverse weather conditions: temperature / brightness / air pressure / excessive or insufficient relative humidity $\left(\mathrm{C}^{\mathrm{II}}{ }_{100}\right)$;

\footnotetext{
*Corresponding author: hvochitoiu@gmail.com
} 
Chemical agents $\left(\mathrm{C}^{\mathrm{II}}{ }_{200}\right)$; Biological agents $\left(\mathrm{C}_{300}\right)$; Dangerous animals / people $\left(\mathrm{C}_{400}{ }^{\mathrm{II}}\right)$; Situations of weather / geological danger, etc. $\left(\mathrm{C}^{\mathrm{II}}{ }_{500}\right)$; Hazardous situations caused by other jobs in the vicinity of the analysed workplace $\left(\mathrm{C}_{600}{ }_{60}\right)$ : Noise $\left(C^{I I}{ }_{601}\right)$; Vibration $\left(C^{I I}{ }_{602}\right)$; Risky activities, carried out at jobs in the vicinity of the analysed workplace $\left(C^{I I}{ }_{603}\right) ; \mathrm{C}^{\mathrm{II}} 700$ other hazardous environmental situations $\left(\mathrm{C}^{\mathrm{II}} 700\right)$.

Category III: Risks produced by the employer and other responsible internal / external factors of the employer with obligations / responsibilities in the field of OSH: Risks produced by the employer when sizing the analysed job with workers $\left(\mathrm{C}^{\mathrm{III}}{ }_{100}\right)$ : If it hires workers who have the appropriate qualification for the analysed job $\left(\mathrm{C}^{\mathrm{III}}{ }_{101}\right)$; If it employs workers who do not have the authorization corresponding to the activities carried out at the analysed workplace $\left(\mathrm{C}^{\mathrm{III}}{ }_{102}\right)$; If it hires workers without the necessary experience for specific activities at the analysed workplace $\left(\mathrm{C}^{\mathrm{III}}{ }_{103}\right)$; Risks posed by persons responsible for training workers in the analysed job $\left(\mathrm{C}^{\mathrm{III}}{ }_{200}\right)$ : General introductory training $\left(\mathrm{C}^{\mathrm{III}}{ }_{201}\right)$; On-the-job training $\left(C^{I I I}{ }_{202}\right)$; Regular training ( $\left.C^{I I I}{ }_{203}\right)$; Training to return to work $\left(C^{I I I} 204\right)$; Risks caused by persons who should ensure the proper functioning of the work equipment that is in the endowment of the assessed job: maintenance / repairs / service, etc. $\left(\mathrm{C}^{\mathrm{III}}{ }_{300}\right)$; Risks produced by the persons who provide with PPE the workers at the analysed workplace $\left(\mathrm{C}^{\mathrm{III}}{ }_{400}\right)$ : Purchase of PPE ( $\mathrm{C}_{401}$ ); PPE compliance ( $\left.\mathrm{C}^{I I I}{ }_{402}\right)$; If the PPE provided provides protection against the identified risks ( $\left.C^{I I I}{ }_{403}\right)$; If the PPE has the correct service life calculated $\left(\mathrm{C}^{I I I}{ }_{404}\right)$; If PPE is replaced whenever necessary $\left(C^{I I I}{ }_{405}\right)$; Risks posed by persons who should monitor the health of workers $\left(\mathrm{C}^{\mathrm{III}}{ }_{500}\right)$ : Medical inspection at employment $\left(\mathrm{C}^{I I I}{ }_{501}\right)$; Periodic medical check-up ( $\left.C^{I I I}{ }_{502}\right)$; Medical examination at the request of the worker $\left(C^{I I I}{ }_{503}\right)$; Risks posed by people who should do special checks and do not do them at the analysed workplace $\left(\mathrm{C}^{\mathrm{III}}{ }_{600}\right)$; Risks posed by persons who should provide OSH signalling in the workplace whether or not they provide staff training $\left(\mathrm{C}^{\mathrm{III}}{ }_{700}\right)$; Risks posed by people who should provide first aid at the analysed workplace $\left(\mathrm{C}^{\mathrm{III}}{ }_{800}\right)$; Risks posed by job managers for the job analysed $\left(\mathrm{C}^{\mathrm{III}}{ }_{900}\right)$ : If they are or not professionally trained $\left(C^{I I I}{ }_{901}\right)$; If the selection is made on the principle of competence ( $\left.C^{I I I} 902\right)$; If they know how to formulate, transmit work tasks and control how them are accomplish ( $\left.C^{I I I}{ }_{903}\right)$; If the situations at the evaluated workplace are managed correctly $\left(C^{I I I}{ }_{904}\right)$.

Category IV: Risks produced by the employee: If he knows the hierarchical structure: direct bosses and big bosses $\left(\mathrm{C}^{\mathrm{IV}}{ }_{100}\right)$; If he knows the significance of the existing signals at the analysed workplace of signs and signals $\left(\mathrm{C}^{\mathrm{IV}}{ }_{200}\right)$; If he know how to use, store, maintenance and replacement of PPE $\left(\mathrm{C}^{\mathrm{IV}} 300\right)$; If he knows how to remedy some nonconformities that may occur at the analysed workplace $\left(\mathrm{C}^{\mathrm{IV}} 400\right)$; If there are working procedures available to the worker and if he knows them $\left(\mathrm{C}^{\mathrm{IV}}{ }_{500}\right)$; If the workers in the job have physical, mental, moral, intellectual, professional qualities corresponding to the analysed job $\left(\mathrm{C}^{\mathrm{IV}}{ }_{600}\right)$; If the workers in the analysed job had disciplinary offenses, occupational diseases, accidents at work or incidents $\left(\mathrm{C}^{\mathrm{IV}} 700\right)$; Other risks generated by the executor in the work process $\left(\mathrm{C}^{\mathrm{IV}} 800\right)$.

The elements highlighted above have a potentially dangerous nature, which determines the risky nature of the work system related to them $[4,5]$.

\section{Research on global risk quantification}

The overall risk level (Nr.) per job is calculated as a weighted average of the risk levels established for the identified risk factors.

In order for the result indicator to reflect reality as accurately as possible, is used as a weighting element the rank of the risk factor, which is equal to the level of risk.

In this way, the factor with the highest level of risk will also have the highest rank, thus eliminating the possibility that the effect of compensation to be between extremes, which 
involves any statistical average, to masks the presence of the factor with the highest level of risk. [6,7].

The formula for calculating the overall risk level is as follows $[8,9]$ :

$$
N_{r}=\frac{\sum_{\mathrm{z}=1}^{n} r_{\mathrm{Z}} \cdot R_{\mathrm{Z}}}{\sum_{\mathrm{z}=1}^{n} r_{\mathrm{z}}}
$$

Where: $\mathrm{N}_{\mathrm{r}}$ is the level of overall risk at the workplace; $\mathrm{r}_{\mathrm{z}}$ - the rank of the risk factor „,z"; $\mathrm{R}_{\mathrm{z}}$ - the level of risk for the risk factor ,z";

Starting from the 5 categories of risk factors listed in the first part, the value ranges of the risk function can be established $\mathrm{F}_{\text {RISK, }}$, thus:

$$
F_{\text {RISK }}=f\left(C^{I^{1} 00}, C^{I I}{ }_{j 0 x}, C^{I I I}{ }_{k 0 y}, C^{I V}{ }_{w 00}\right),
$$

Where:

1. $\mathrm{C}_{\mathrm{i} 00}=$ Category $\mathrm{I}$, risks posed by the work equipment available and the materials and substances used, with $\mathrm{i}=1 \div 5$, from where results the following category components: $\mathrm{C}_{100}^{\mathrm{I}}, \mathrm{C}^{\mathrm{I}}{ }_{200}, \mathrm{C}^{\mathrm{I}}{ }_{300}, \mathrm{C}_{400}^{\mathrm{I}}$ and

2. $\mathrm{C}_{500}^{\mathrm{I}}$;

3. $\mathrm{C}_{\mathrm{j} 0 \mathrm{x}}^{\mathrm{II}}=$ Category II, risks produced by the work environment in which the worker is in the work process, with $\mathrm{j}=1 \div 7$ and $\mathrm{x}=0$, hence the following components of category: $\mathrm{C}_{100}{ }_{10}, \mathrm{C}^{\mathrm{II}_{200}}, \mathrm{C}^{\mathrm{II}}{ }_{300}, \mathrm{C}_{400}{ }_{40}, \mathrm{C}^{\mathrm{II}}{ }_{500}, \mathrm{C}_{600}^{\mathrm{II}}$ and $\mathrm{C}^{\mathrm{II}}{ }_{700}$. For $\mathrm{j}=6$ and $\mathrm{x}=1 \div 3$ the following subcategory components result: $\mathrm{C}^{\mathrm{II}}{ }_{601}, \mathrm{C}^{\mathrm{II}}{ }_{602}$ and $\mathrm{C}^{\mathrm{II}}{ }_{603}$;

4. $\mathrm{C}^{\mathrm{III}} \mathrm{ky}=$ Category III of risks posed by the employer and other responsible internal and external factors to the employer who according to the law have certain obligations and responsibilities in the field of $\mathrm{OSH}$, with $\mathrm{k}=1 \div 9$ and $\mathrm{y}=0$, where from the following category components result: $\mathrm{C}^{\mathrm{III}}{ }_{100}, \mathrm{C}^{\mathrm{III}}{ }_{200}$, $\mathrm{C}^{\mathrm{III}}{ }_{300}, \mathrm{C}_{400}^{\mathrm{III}}, \mathrm{C}_{500}{ }^{\mathrm{III}}, \mathrm{C}_{600}{ }_{60}, \mathrm{C}^{\mathrm{III}}{ }_{700}, \mathrm{C}^{\mathrm{III}}{ }_{800}$ and $\mathrm{C}^{\mathrm{III}}{ }_{900}$. For $\mathrm{k}=2$ and $\mathrm{y}=1 \div 4$ the following subcategory components result: $\mathrm{C}_{201}^{\mathrm{III}}, \mathrm{C}_{202}^{\mathrm{III}}, \mathrm{C}_{203}^{\mathrm{III}}$ and $\mathrm{C}_{204}{ }_{204}$; For $\mathrm{k}=4$ and $\mathrm{y}=1 \div 5$ the following subcategory components result: $\mathrm{C}^{\mathrm{III}}{ }_{401}, \mathrm{C}^{\mathrm{III}}{ }_{402}$, $\mathrm{C}^{\mathrm{III}} 403, \mathrm{C}^{\mathrm{III}} 404$ and $\mathrm{C}^{\mathrm{III}} 405$; For $\mathrm{k}=5$ and $\mathrm{y}=1 \div 3$ the following subcategory components result: $\mathrm{C}^{\mathrm{III}}{ }_{501}, \mathrm{C}^{\mathrm{III}}{ }_{502}$ and $\mathrm{C}^{\mathrm{III}}{ }_{503}$; For $\mathrm{k}=9$ and $\mathrm{y}=1 \div 4$ the following subcategory components result: $\mathrm{C}^{\mathrm{III}}{ }_{901}, \mathrm{C}^{\mathrm{III}}{ }_{902}, \mathrm{C}^{\mathrm{III}}{ }_{903}$ and $\mathrm{C}^{\mathrm{III}}{ }_{904}$;

5. $\mathrm{C}^{\mathrm{IV}}{ }_{\mathrm{w} 00}=$ Category IV of risks produced by the employee, with $\mathrm{w}=1 \div 8$, where from, the following category components result $\mathrm{C}^{\mathrm{IV}}{ }_{100}, \mathrm{C}^{\mathrm{IV}}{ }_{200}, \mathrm{C}^{\mathrm{IV}}{ }_{300}, \mathrm{C}^{\mathrm{IV}}{ }_{400}$, $\mathrm{C}^{\mathrm{IV}}{ }_{500}, \mathrm{C}^{\mathrm{IV}}{ }_{600}, \mathrm{C}^{\mathrm{IV}} 700$ and $\mathrm{Cl}_{800}^{\mathrm{IV}}$.

\section{Determining the rank of the generic risk factor $z$}

To determine the value of the generic risk factor $\mathrm{z}$ rank, we took into account the quantitative ratio that exists at the category and subcategory level, transforming the weighting result into a scaled value that is the momentary value of the value range corresponding to the risk factor $\mathrm{z}$ rank, respectively:

6. For Category I risks posed by the work equipment available and the materials / substances used $\left(\mathrm{C}^{\mathrm{I}}{ }_{\mathrm{i} 00}\right)$, we have: $\mathrm{r}_{\mathrm{Cl} i 00}=\mathrm{r}_{\mathrm{z}}$ where $\mathrm{i}=1 \div 5$;

7. For Category II of risks produced by the work environment in which the worker is in the work process $\left(\mathrm{C}^{\mathrm{II} 0 \mathrm{x}}\right)$, we have: $\mathrm{r}_{\mathrm{CIj} j \mathrm{O}}=\mathrm{r}_{\mathrm{z}}$, where $\mathrm{j}=1 \div 5$ and $\mathrm{j}=7$ and $\mathrm{x}=0$; For $\mathrm{j}=6$ and $\mathrm{x}=1 \div 3$ we have $\mathrm{r}_{\mathrm{CII} 60 \mathrm{x}}=0.33 * \mathrm{r}_{\mathrm{z}}$;

Taking into account the aspects mentioned above, the relation (1) becomes:

$$
N=\frac{\sum_{z=1}^{n} r_{z \cdot} \cdot f_{z \cdot} \cdot\left(C_{i 00}^{I}, C_{j 0 x}^{I I}\right.}{\sum_{z=1}^{n} r_{z}}
$$

where: $\mathrm{i}=1 \div 5$ and $\mathrm{j}=1 \div 7$, and $\mathrm{z}$ represents the number of identified risk factors 
The general picture regarding the determination of the rank of the generic risk factor " $z$ " for its use in the calculation formula for determining the overall level of risk, it has the following form (Table 1):

Table 1. Determination of the rank of the generic risk factor " $z$ "

\begin{tabular}{|c|c|c|c|c|c|}
\hline \multirow{2}{*}{$\begin{array}{c}\text { Risk category } \\
C^{\mathbf{I}} \mathbf{i 0 0}\end{array}$} & \multicolumn{2}{|c|}{$\begin{array}{l}\text { The fact of } \\
\text { multiplying } \\
\text { the rank of } \\
\text { the risk } \\
\text { factor, } \\
\text { associated } \\
\text { with the risk } \\
\text { category }\end{array}$} & \multirow[t]{2}{*}{$\begin{array}{c}\text { Subcategory } \\
\text { of risks }\end{array}$} & \multirow[t]{2}{*}{$\begin{array}{c}\text { The fact of } \\
\text { multiplying } \\
\text { the rank of } \\
\text { the risk } \\
\text { factor, } \\
\text { associated } \\
\text { with the risk } \\
\text { subcategory }\end{array}$} & \multirow{2}{*}{$\begin{array}{c}\begin{array}{c}\text { Analytical } \\
\text { relationship } \\
\text { of rank } \\
\mathrm{r}_{\mathrm{Z}}\end{array} \\
\\
\mathrm{r}_{\mathrm{CI} 100}=1.00 * \mathrm{r}_{\mathrm{Z}} \\
\mathrm{r}_{\mathrm{CI} 200}=1.00 * \mathrm{r}_{\mathrm{Z}} \\
\mathrm{r}_{\mathrm{C} 1300}=1.00 * \mathrm{r}_{\mathrm{Z}} \\
\mathrm{r}_{\mathrm{CI} 400}=1.00 * \mathrm{r}_{\mathrm{Z}} \\
\mathrm{r}_{\mathrm{CI500}}=1.00 * \mathrm{r}_{\mathrm{Z}}\end{array}$} \\
\hline & $\begin{array}{l}\mathrm{C}^{\mathrm{I}}{ }_{100} \\
\mathrm{C}^{\mathrm{I}}{ }_{200} \\
\mathrm{C}^{\mathrm{I}}{ }_{300} \\
\mathrm{C}^{\mathrm{I}}{ }_{400} \\
\mathrm{C}_{500}^{\mathrm{I}}\end{array}$ & $\begin{array}{l}1.00 \\
1.00 \\
1.00 \\
1.00 \\
1.00\end{array}$ & & & \\
\hline \multirow[t]{3}{*}{$\mathrm{C}^{\mathrm{II}}{ }_{\mathrm{j} 0 \mathrm{x}}$} & $\begin{array}{l}\mathrm{C}^{\mathrm{II}}{ }_{100} \\
\mathrm{C}^{\mathrm{II}} 200 \\
\mathrm{C}^{\mathrm{II}} 300 \\
\mathrm{C}^{\mathrm{II}} 400 \\
\mathrm{C}^{\mathrm{II}}{ }_{500}\end{array}$ & $\begin{array}{l}1.00 \\
1.00 \\
1.00 \\
1.00 \\
1.00\end{array}$ & & & $\begin{array}{l}\mathrm{r}_{\mathrm{CII} 100}=1.00 * \mathrm{r}_{\mathrm{z}} \\
\mathrm{r}_{\mathrm{CII} 200}=1.00 * \mathrm{r}_{\mathrm{z}} \\
\mathrm{r}_{\mathrm{CII} 300}=1.00 * \mathrm{r}_{\mathrm{z}} \\
\mathrm{r}_{\mathrm{CII} 400}=1.00 * \mathrm{r}_{\mathrm{z}} \\
\mathrm{r}_{\mathrm{CII} 500}=1.00 * \mathrm{r}_{\mathrm{z}}\end{array}$ \\
\hline & $\mathrm{C}_{600}$ & & $\begin{array}{l}\mathrm{C}^{\mathrm{II}}{ }_{601} \\
\mathrm{C}^{\mathrm{II}}{ }_{602} \\
\mathrm{C}^{\mathrm{II}}{ }_{603}\end{array}$ & $\begin{array}{l}0.33 \\
0.33 \\
0.33\end{array}$ & $\begin{array}{l}\mathrm{r}_{\mathrm{CII} 601}=0.33 * \mathrm{r}_{\mathrm{Z}} \\
\mathrm{r}_{\mathrm{CII} 602}=0.33 * \mathrm{r}_{\mathrm{z}} \\
\mathrm{r}_{\mathrm{CII} 603}=0.33 * \mathrm{r}_{\mathrm{z}}\end{array}$ \\
\hline & $\mathrm{C}_{700}^{\mathrm{II}}$ & 1.00 & & & $\mathrm{r}_{\mathrm{CII} 700}=1.00 * \mathrm{r}_{\mathrm{z}}$ \\
\hline
\end{tabular}

In the case of most assessment methods, the risk factors are analysed only for the basic location of the workplace and for the other temporary or accidental locations, separate assessments are made.

If we agree that for a type of job to be assessed, the sets of risk factors at each location where the assessed worker ends up working must be taken into account, in which case it must be seen for each type of job separately, what are the risk factors that can affect the worker while he is in that location and all of them together to compose a set of risk factors for the analysed location.

In this way the assessor is obliged to identify more risk factors than usual and from more locations than the base location and the temporary location.

In this case, the relationship $\left(1^{*}\right)$ becomes:

$$
N=\frac{\sum_{Z=1}^{n} r^{*}{ }_{z} \cdot f_{Z} \cdot\left(C_{i 00}^{I}, C_{j 0 x}^{I I}\right.}{\sum_{Z=1}^{n} r_{Z}}
$$

where: $\mathrm{r}_{\mathrm{z}}^{*}=\mathrm{e}(\%) / 100 * \mathrm{r}_{\mathrm{z}}$ and $\mathrm{e}(\%)$ represents the temporary exposure to the action of the risk factors present in the temporary location, expressed as a percentage of the normal working time (correction of the rank of the risk factor depending on the temporary or total exposure 
to the action of the risk factors $)^{1} ; \mathrm{i}=1 \div 5$ and $\mathrm{j}=1 \div 7$ and $\mathrm{z}$ represents the number of identified risk factors.

Note $^{l}$ : In the case of a total exposure (ie throughout the normal working time) we have $e$ $(\%) / 100=100 / 100=1.00$ and $r_{z}^{*}=1.00 * r_{z}=r_{z}$

\section{Presentation of the evaluation results}

In the case of a total exposure, we obtain the results from table 2.

Table 2. Determination of the rank based on the total exposure

\begin{tabular}{|c|c|c|c|c|c|c|}
\hline \multirow{3}{*}{$\begin{array}{c}\text { Risk } \\
\text { category }\end{array}$} & \multirow{2}{*}{\multicolumn{2}{|c|}{$\begin{array}{l}\text { The fact of } \\
\text { multiplying the } \\
\text { rank of the risk } \\
\text { factor, associated } \\
\text { with the risk } \\
\text { category }\end{array}$}} & \multirow{3}{*}{$\begin{array}{c}\text { Risk } \\
\text { subcategory }\end{array}$} & \multicolumn{2}{|c|}{$\begin{array}{c}\text { The fact of } \\
\text { multiplying the } \\
\text { rank of the risk } \\
\text { factor, associated } \\
\text { with the risk } \\
\text { subcategory }\end{array}$} & \multirow[t]{3}{*}{$\begin{array}{c}\begin{array}{c}\text { Analytical relation } \\
\text { of rank }\end{array} \\
\begin{array}{c}{[\mathrm{e}(\%) / 100] * \mathrm{r}^{*}{ }_{\mathrm{z}}=} \\
=[\mathrm{e}(\%) / 100] * 1.00 * \\
\mathrm{r}_{\mathrm{z}}\end{array}\end{array}$} \\
\hline & & & & \multirow{2}{*}{$\begin{array}{c}\text { The } \\
\text { value of } \\
\text { the } \\
\text { multiplic } \\
\text { ation } \\
\text { fact }\end{array}$} & \multirow[b]{2}{*}{$\begin{array}{c}\mathrm{e}(\%) / 1 \\
00\end{array}$} & \\
\hline & $\begin{array}{l}\text { The value } \\
\text { of the } \\
\text { multiplic } \\
\text { ation fact }\end{array}$ & $\begin{array}{l}\text { e(\%) } \\
/ 100\end{array}$ & & & & \\
\hline $\mathbf{C}_{\mathrm{i} \mathbf{0 0}}^{\mathbf{I}}$ & $\begin{array}{l}\mathrm{C}_{100}^{\mathrm{I}_{1}} \\
\mathrm{C}_{200} \\
\mathrm{C}_{200} \\
\mathrm{C}_{300} \mathrm{I}_{400} \\
\mathrm{C}_{500}^{\mathrm{I}} \\
\end{array}$ & $\begin{array}{l}1.00 \\
1.00 \\
1.00 \\
1.00 \\
1.00 \\
\end{array}$ & & & & $\begin{array}{l}\mathrm{r}_{\mathrm{CI} 100}=1.00 * 1.00 * \mathrm{r}_{\mathrm{Z}} \\
\mathrm{r}_{\mathrm{CI} 200}=1.00 * 1.00 * \mathrm{r}_{\mathrm{Z}} \\
\mathrm{r}_{\mathrm{CI} 300}=1.00 * 1.00 * \mathrm{r}_{\mathrm{Z}} \\
\mathrm{r}_{\mathrm{CI} 400}=1.00 * 1.00 * \mathrm{r}_{\mathrm{Z}} \\
\mathrm{r}_{\mathrm{CI} 500}=1.00 * 1.00 * \mathrm{r}_{\mathrm{z}}\end{array}$ \\
\hline \multirow[t]{3}{*}{$\mathrm{C}^{\mathrm{II}_{\mathrm{j} 0 \mathrm{x}}}$} & $\begin{array}{l}\mathrm{C}^{\mathrm{II}}{ }_{100} \\
\mathrm{C}^{\mathrm{II}} 200 \\
\mathrm{C}^{\mathrm{CI}_{300}} \\
\mathrm{C}^{\mathrm{Cl}^{4}}{ }^{400} \\
\mathrm{C}^{\mathrm{II}}{ }_{500} \\
\end{array}$ & $\begin{array}{l}1.00 \\
1.00 \\
1.00 \\
1.00 \\
1.00\end{array}$ & & & & $\begin{array}{l}\mathrm{r}_{\mathrm{CII} 100}=1.00 * 1.00 * \mathrm{r}_{\mathrm{z}} \\
\mathrm{r}_{\mathrm{CII} 200}=1.00 * 1.00 * \mathrm{r}_{\mathrm{Z}} \\
\mathrm{r}_{\mathrm{CII} 300}=1.00 * 1.00 * \mathrm{r}_{\mathrm{Z}} \\
\mathrm{r}_{\mathrm{CII} 400}=1.00 * 1.00 * \mathrm{r}_{\mathrm{Z}} \\
\mathrm{r}_{\mathrm{CII} 500}=1.00 * 1.00 * \mathrm{r}_{\mathrm{Z}}\end{array}$ \\
\hline & $\mathrm{C}^{\mathrm{II}_{600}}$ & & $\begin{array}{l}\mathrm{Cl}^{\mathrm{II}}{ }_{601} \\
\mathrm{C}^{\mathrm{II}}{ }_{602} \\
\mathrm{C}^{\mathrm{II}}{ }_{603}\end{array}$ & $\begin{array}{l}0.33 \\
0.33 \\
0.33\end{array}$ & $\begin{array}{l}1.00 \\
1.00 \\
1.00\end{array}$ & $\begin{array}{l}\mathrm{r}_{\mathrm{CII} 601}=0.33 * 1.00 * \mathrm{rZ} \\
\mathrm{r}_{\mathrm{CII} 602}=0.33 * 1.00 * \mathrm{rZ} \\
\mathrm{r}_{\mathrm{CII} 603}=0.33 * 1.00 * \mathrm{rZ} \\
\mathrm{r}_{\mathrm{CII} 700}=1.00 * 1.00 * \mathrm{rZ}\end{array}$ \\
\hline & $\mathrm{C}^{\mathrm{II}} 700$ & 1.00 & & & & \\
\hline
\end{tabular}

In the case of a normal 8-hour work schedule, the values of the risk factor correction coefficient according to the exposure $(\mathrm{e}(\%) / 100)$ are shown in Table 3 and its values $\mathrm{r}^{*}$ in the table 4:

Table 3. The values of the risk factor correction coefficient

\begin{tabular}{|c|c|c|c|c|c|c|c|c|}
\hline & $1 \mathrm{~h}$ & $2 \mathrm{~h}$ & $3 \mathrm{~h}$ & $4 \mathrm{~h}$ & $5 \mathrm{~h}$ & $6 \mathrm{~h}$ & $7 \mathrm{~h}$ & $8 \mathrm{~h}$ \\
\hline $\mathrm{e}(\%) / 100$ & 0.125 & 0.250 & 0.375 & 0.500 & 0.625 & 0.750 & 0.875 & 1.000 \\
\hline
\end{tabular}


Table 4. The rank value depending on the exposure

\begin{tabular}{|c|c|c|c|c|c|c|c|}
\hline \multirow{2}{*}{\multicolumn{2}{|c|}{$\begin{array}{l}\text { Category of } \\
\text { risks }\end{array}$}} & \multicolumn{2}{|c|}{$\begin{array}{l}\text { The fact of } \\
\text { multiplying the rank } \\
\text { of the risk factor, } \\
\text { associated with the } \\
\text { risk category } \\
\text { according to the } \\
\text { hourly exposure }\end{array}$} & \multirow[t]{2}{*}{$\begin{array}{c}\text { Subcateg } \\
\text { ory of } \\
\text { risks }\end{array}$} & \multicolumn{2}{|c|}{$\begin{array}{l}\text { The fact of } \\
\text { multiplying the } \\
\text { rank of the risk } \\
\text { factor, associated } \\
\text { with the risk } \\
\text { subcategory }\end{array}$} & \multirow[t]{2}{*}{$\begin{array}{c}\text { Rank } \\
\text { value } \\
\text { depending } \\
\text { on the } \\
\text { exposure } \\
\mathrm{r}^{*}{ }_{\mathrm{z}}=\mathrm{e}(\%) / 1 \\
00 * \mathrm{r}_{\mathrm{z}}\end{array}$} \\
\hline & & $\begin{array}{l}\text { The } \\
\text { value of } \\
\text { the } \\
\text { multipli } \\
\text { cation } \\
\text { fact }\end{array}$ & $\mathrm{e}_{\mathrm{xh}}(\%) / 100$ & & $\begin{array}{l}\text { The } \\
\text { value of } \\
\text { the } \\
\text { multipli } \\
\text { cation } \\
\text { fact }\end{array}$ & $\mathrm{e}_{\mathrm{xh}}(\%) / 100$ & \\
\hline $\mathbf{C}^{\mathbf{I}} \mathbf{i 0 0}$ & $\begin{array}{l}\mathrm{C}^{\mathrm{I}} 100 \\
\mathrm{C}_{200} \\
\mathrm{C}_{300}^{\mathrm{I}_{3}} \\
\mathrm{C}_{400}^{\mathrm{I}_{4}} \\
\mathrm{C}^{\mathrm{I}_{500}}\end{array}$ & $\begin{array}{l}1.00 \\
1.00 \\
1.00 \\
1.00 \\
1.00 \\
1.00 \\
1.00 \\
1.00\end{array}$ & $\begin{array}{l}0.125_{\mathrm{hh}} \\
0.250_{2 \mathrm{~h}} \\
0.375_{3 \mathrm{~h}} \\
0.500_{4 \mathrm{~h}} \\
0.625_{5 \mathrm{~h}} \\
0.750_{6 \mathrm{~h}} \\
0.875_{\mathrm{hh}} \\
1.000_{\mathrm{hh}}\end{array}$ & & & & $\begin{array}{l}0.125 \\
0.250 \\
0.375 \\
0.500 \\
0.625 \\
0.750 \\
0.875 \\
1.000\end{array}$ \\
\hline \multirow{3}{*}{$\mathbf{C}^{\mathrm{II}_{\mathrm{j} 0 \mathrm{x}}}$} & \multirow[t]{2}{*}{$\begin{array}{l}\mathrm{C}^{\mathrm{II}}{ }_{100} \\
\mathrm{Cl}_{200} \\
\mathrm{Cl}^{\mathrm{II}}{ }_{300} \\
\mathrm{C}^{\mathrm{II}} 400 \\
\mathrm{Cl}^{\mathrm{II}} 500 \\
\mathrm{C}^{\mathrm{II}}{ }_{700}\end{array}$} & $\begin{array}{l}1.00 \\
1.00 \\
1.00 \\
1.00 \\
1.00 \\
1.00\end{array}$ & $\begin{array}{l}0.125_{1 \mathrm{~h}} \\
0.250_{2 \mathrm{~h}} \\
0.375_{3 \mathrm{~h}} \\
0.500_{4 \mathrm{~h}} \\
0.625_{5 \mathrm{~h}} \\
0.750_{6 \mathrm{~h}}\end{array}$ & & & & $\begin{array}{l}0.125 \\
0.250 \\
0.375 \\
0.500 \\
0.625 \\
0.750\end{array}$ \\
\hline & & $\begin{array}{l}1.00 \\
1.00 \\
\end{array}$ & $\begin{array}{l}0.875_{7 \mathrm{~h}} \\
1.000_{8 \mathrm{~h}}\end{array}$ & & & & $\begin{array}{l}0.875 \\
1.000 \\
\end{array}$ \\
\hline & $\mathrm{C}^{\mathrm{II}}{ }_{600}$ & & & $\begin{array}{l}\mathrm{Cl}^{\mathrm{II}}{ }_{601} \\
\mathrm{C}^{\mathrm{II}}{ }_{602} \\
\mathrm{C}^{\mathrm{II}}{ }_{603}\end{array}$ & 0.33 & $\begin{array}{l}0.125^{1 \mathrm{~h}} \\
0.250^{2 \mathrm{~h}} \\
0.375^{3 \mathrm{~h}} \\
0.500^{4 \mathrm{~h}} \\
0.625^{5 \mathrm{~h}} \\
0.750^{6 \mathrm{~h}} \\
0.875^{\text {hh }} \\
1.000^{\mathrm{h}}\end{array}$ & $\begin{array}{l}0.041 \\
0.082 \\
0.123 \\
0.165 \\
0.206 \\
0.247 \\
0.288 \\
0.330\end{array}$ \\
\hline $\mathrm{C}^{\mathrm{III}} \mathrm{k}_{\mathrm{y}}$ & $\begin{array}{l}\mathrm{C}^{\mathrm{III}}{ }_{100} \\
\mathrm{C}^{\mathrm{III}} 300 \\
\mathrm{C}^{\mathrm{III}}{ }_{500} \\
\mathrm{C}^{\mathrm{IIII}} 600 \\
\mathrm{C}^{\mathrm{III}} 7_{700} \\
\mathrm{C}^{\mathrm{III}} 800\end{array}$ & $\begin{array}{l}1.00 \\
1.00 \\
1.00 \\
1.00 \\
1.00 \\
1.00 \\
1.00 \\
1.00\end{array}$ & $\begin{array}{l}0.125_{\mathrm{hh}} \\
0.250_{2 \mathrm{~h}} \\
0.375_{3 \mathrm{~h}} \\
0.500_{4 \mathrm{~h}} \\
0.625_{5 \mathrm{~h}} \\
0.750_{6 \mathrm{~h}} \\
0.875_{7 \mathrm{~h}} \\
1.000_{8 \mathrm{~h}}\end{array}$ & & & & $\begin{array}{l}0.125 \\
0.250 \\
0.375 \\
0.500 \\
0.625 \\
0.750 \\
0.875 \\
1.000\end{array}$ \\
\hline
\end{tabular}




\begin{tabular}{|c|c|c|c|c|c|c|c|}
\hline & $\mathrm{C}^{\mathrm{III}}{ }_{200}$ & & & $\begin{array}{l}\mathrm{C}^{\mathrm{IIII}}{ }_{201} \\
\mathrm{C}^{\mathrm{III}}{ }_{202} \\
\mathrm{C}^{\mathrm{III}}{ }_{203} \\
\mathrm{C}^{\mathrm{III}}{ }_{204}\end{array}$ & 0.25 & $\begin{array}{c}0.125^{1 \mathrm{~h}} \\
0.250^{2 \mathrm{~h}} \\
0.375^{\text {hh }} \\
0.500^{4 \mathrm{~h}} \\
0.625^{5 \mathrm{~h}} \\
0.750^{6 \mathrm{~h}} \\
0.875^{\text {hh }} \\
1.000^{\mathrm{h}}\end{array}$ & $\begin{array}{l}0.031 \\
0.062 \\
0.093 \\
0.125 \\
0.156 \\
0.187 \\
0.218 \\
0.250\end{array}$ \\
\hline & $\mathrm{C}^{\mathrm{III}} 400$ & & & 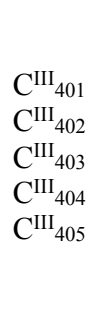 & 0.20 & $\begin{array}{c}0.125^{1 h} \\
0.250^{2 h} \\
0.375^{3 h} \\
0.500^{4 h} \\
0.625^{5 h} \\
0.750^{6 h} \\
0.875^{7 h} \\
1.000^{h}\end{array}$ & $\begin{array}{l}0.025 \\
0.050 \\
0.075 \\
0.100 \\
0.125 \\
0.150 \\
0.175 \\
0.200\end{array}$ \\
\hline & $\mathrm{C}^{\mathrm{III}}{ }_{900}$ & & & $\begin{array}{l}\mathrm{C}^{\mathrm{IIII}}{ }_{901} \\
\mathrm{C}^{\mathrm{III}}{ }_{902} \\
\mathrm{C}^{\mathrm{III}}{ }_{903} \\
\mathrm{C}^{\mathrm{III}}{ }_{904}\end{array}$ & 0.25 & $\begin{array}{c}0.125^{\text {th }} \\
0.250^{2 \mathrm{~h}} \\
0.375^{\text {hh }} \\
0.500^{\text {hh }} \\
0.625^{\text {hh }} \\
0.750^{6 \mathrm{~h}} \\
0.875^{\text {h }} \\
1.000^{\mathrm{h}}\end{array}$ & $\begin{array}{l}0.031 \\
0.062 \\
0.093 \\
0.125 \\
0.156 \\
0.187 \\
0.218 \\
0.250\end{array}$ \\
\hline $\mathrm{C}^{\mathbf{I V}}{ }_{\mathrm{w00}}$ & $\begin{array}{l}\mathrm{C}^{\mathrm{IV}}{ }_{100} \\
\mathrm{C}^{\mathrm{IV}} \mathrm{V}_{200} \\
\mathrm{C}^{\mathrm{IV}}{ }_{300} \\
\mathrm{C}^{\mathrm{IV}} \mathrm{V}_{400} \\
\mathrm{C}^{\mathrm{IV}}{ }_{500} \\
\mathrm{C}^{\mathrm{IV}}{ }_{600} \\
\mathrm{C}^{\mathrm{IV}} \mathrm{C}_{700} \\
\mathrm{C}^{\mathrm{IV}}{ }_{800}\end{array}$ & $\begin{array}{l}1.00 \\
1.00 \\
1.00 \\
1.00 \\
1.00 \\
1.00 \\
1.00 \\
1.00\end{array}$ & $\begin{array}{l}0.125_{1 \mathrm{~h}} \\
0.250_{2 \mathrm{~h}} \\
0.375_{3 \mathrm{~h}} \\
0.500_{4 \mathrm{~h}} \\
0.6255_{\mathrm{h}} \\
0.750_{6 \mathrm{~h}} \\
0.875_{7 \mathrm{~h}} \\
1.000_{\mathrm{hh}}\end{array}$ & & & & $\begin{array}{l}0.125 \\
0.250 \\
0.375 \\
0.500 \\
0.625 \\
0.750 \\
0.875 \\
1.000\end{array}$ \\
\hline
\end{tabular}

The method of calculating the coefficients of specific risk categories $C^{I I I}$ and $C^{I V}$

Coefficients for the risks in the categories $\mathrm{C}^{\mathrm{III}}$ and $\mathrm{C}^{\mathrm{IV}}$, it is calculated according to how many major non-conformities are unresolved, based on the multi-criteria analysis.

- For risks in the category $\mathrm{C}^{\mathrm{III}}$

The particular case where all 10 criteria are equally weighted (equally important), $\alpha_{i}=0.1$, $i=1 \div 10$, table 5 . 
Table 5. Results for the specific risk in the category $\mathrm{C}^{\mathrm{III}}$

\begin{tabular}{|c|c|c|c|c|c|c|}
\hline \multirow{2}{*}{ 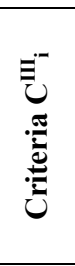 } & \multirow[b]{2}{*}{ Criterion name } & \multicolumn{2}{|c|}{$\begin{array}{c}\text { Compliance/num } \\
\text { ber of items }\end{array}$} & \multirow{2}{*}{$\begin{array}{c}\text { Appreci- } \\
\text { ation } \\
\text { parameter, } \\
\mathbf{x}_{\text {med }}\end{array}$} & \multirow{2}{*}{$\begin{array}{l}\text { Weightin } \\
\text { g value of } \\
\text { the } \\
\text { criterion } \\
\text { C III }_{i}, \alpha_{i}\end{array}$} & \multirow{2}{*}{$\begin{array}{c}\text { Level of the } \\
\text { fulfilment } \\
\text { of the } \\
\text { criterion } \\
C^{\text {III }} \text {, } \\
N_{\mathrm{i}}=\exp [(- \\
\left.\left.\alpha_{\mathrm{i}}\right)\left(1-\mathbf{x}_{\text {med }}\right)\right]\end{array}$} \\
\hline & & Yes & No & & & \\
\hline $\mathrm{C}^{\mathrm{III}}{ }_{1}$ & $\begin{array}{c}\text { Authorization / assessment } \\
\text { / plan }\end{array}$ & 4 & 0 & 1.00 & 0.10 & 1.00 \\
\hline $\mathrm{C}^{\mathrm{III}}{ }_{2}$ & $\begin{array}{c}\text { Dangerous substances, } \\
\text { Ex environments, ISCIR }\end{array}$ & 5 & 0 & 1.00 & 0.10 & 1.00 \\
\hline $\mathrm{C}^{\mathrm{III}}{ }_{3}$ & $\begin{array}{c}\text { Person responsible for } \\
\text { OSH }\end{array}$ & 4 & 0 & 1.00 & 0.10 & 1.00 \\
\hline $\mathrm{C}^{\mathrm{III}}{ }_{4}$ & OSH documentation & 5 & 0 & 1.00 & 0.10 & 1.00 \\
\hline $\mathrm{C}^{\mathrm{III}}{ }_{5}$ & Work equipment & 5 & 0 & 1.00 & 0.10 & 1.00 \\
\hline $\mathrm{C}^{\mathrm{IIII}}{ }_{6}$ & Signaling and display & 4 & 0 & 1.00 & 0.10 & 1.00 \\
\hline $\mathrm{C}^{\mathrm{III}} \mathrm{I}_{7}$ & $\begin{array}{c}\text { Personal protective } \\
\text { equipment }\end{array}$ & 5 & 0 & 1.00 & 0.10 & 1.00 \\
\hline $\mathrm{C}^{\mathrm{III}} \mathrm{I}_{8}$ & Occupation of the position & 4 & 0 & 1.00 & 0.10 & 1.00 \\
\hline $\mathrm{CIII}_{9}$ & Employee training & 5 & 0 & 1.00 & 0.10 & 1.00 \\
\hline $\mathrm{C}^{\mathrm{III}}{ }_{10}$ & $\begin{array}{c}\text { Monitoring health and first } \\
\text { aid }\end{array}$ & 5 & 0 & 1.00 & 0.10 & 1.00 \\
\hline \multicolumn{2}{|r|}{$\mathbf{N}_{\text {global }}=\Sigma \alpha_{\mathrm{i}} \mathbf{N}_{\mathrm{i}}$} & \multicolumn{5}{|c|}{1.00} \\
\hline \multicolumn{2}{|r|}{$\mathrm{N}_{\text {affectation }}=1-\mathrm{N}_{\text {global }}$} & \multicolumn{5}{|c|}{0.00} \\
\hline
\end{tabular}

- For risks in the category $\mathrm{C}^{\mathrm{IV}}$

The particular case in which all 8 criteria are equally weighted (equally important), $\alpha_{\mathrm{i}}=0.1$, $i=1 \div 8$, (table 6 ):

Table 6. Results for the specific risk in the category $\mathrm{C}^{\mathrm{IV}}$

\begin{tabular}{|c|c|c|c|c|c|c|}
\hline \multirow{2}{*}{ } & \multirow[b]{2}{*}{ Criterion name } & \multicolumn{2}{|c|}{$\begin{array}{c}\text { Compliance/num } \\
\text { ber of items }\end{array}$} & \multirow{2}{*}{\begin{tabular}{|} 
Appreci- \\
ation \\
parameter, \\
$\mathbf{x}_{\text {med }}$
\end{tabular}} & \multirow{2}{*}{$\begin{array}{l}\text { Weightin } \\
\text { g value of } \\
\text { the } \\
\text { criterion } \\
\text { C III }^{\text {II }}, \alpha_{i}\end{array}$} & \multirow{2}{*}{$\begin{array}{c}\text { Level of the } \\
\text { fulfilment } \\
\text { of the } \\
\text { criterion } \\
\text { CIII, } \\
N_{\mathrm{i}}=\exp [(- \\
\left.\left.\alpha_{\mathrm{i}}\right)\left(1-\mathrm{x}_{\mathrm{med}}\right)\right]\end{array}$} \\
\hline & & Yes & No & & & \\
\hline $\mathrm{C}^{\mathrm{IV}}{ }_{1}$ & Education & 4 & 0 & 1.00 & 0.10 & 1.00 \\
\hline $\mathrm{ClV}_{2}$ & Equipment supplied & 4 & 0 & 1.00 & 0.10 & 1.00 \\
\hline $\mathrm{ClV}_{3}$ & Protection equipment & 3 & 0 & 1.00 & 0.10 & 1.00 \\
\hline $\mathrm{C}^{\mathrm{IV}} \mathrm{H}_{4}$ & $\begin{array}{l}\text { Dangerous substances, Ex } \\
\text { environments etc. }\end{array}$ & 4 & 0 & 1.00 & 0.10 & 1.00 \\
\hline $\mathrm{ClV}_{5}$ & SSM signaling & 2 & 0 & 1.00 & 0.10 & 1.00 \\
\hline $\mathrm{C}^{\mathrm{IV}} \mathrm{f}_{6}$ & PSI & 2 & 0 & 1.00 & 0.10 & 1.00 \\
\hline $\mathrm{C}^{\mathrm{IV}} \mathrm{v}_{7}$ & First aid & 3 & 0 & 1.00 & 0.10 & 1.00 \\
\hline $\mathrm{C}^{\mathrm{IV}}{ }_{8}$ & Health surveillance & 3 & 2 & 1.00 & 0.10 & 1.00 \\
\hline & $\mathbf{N}_{\text {total }}=\Sigma \alpha_{\mathrm{i}} \mathbf{N}_{\mathrm{i}}$ & \multicolumn{5}{|c|}{1.00} \\
\hline & $N_{\text {affectation }}=1-N_{\text {total }}$ & \multicolumn{5}{|c|}{0.00} \\
\hline
\end{tabular}

The concordance between the level of affectation ( $\mathrm{N}$ affectation) and the level of risk ( $\mathrm{N}$ risk)

\begin{tabular}{|c|c|c|c|c|c|c|c|}
\hline $\mathrm{N}_{\text {affectation }}$ & 0.00 & 0.25 & 0.40 & 0.55 & 0.70 & 0.85 & 1.00 \\
\hline $\mathrm{N}_{\text {risk }}$ & 1 & 2 & 3 & 4 & 5 & 6 & 7 \\
\hline
\end{tabular}




\section{Interpretation of the obtained results}

The results of the risk assessment provide relevant data and information on the state of safety and health at work specific to the activities carried out, in order to optimize the mechanism for substantiating policies in the field of preventing and combating causes that may lead to accidents at work and / or occupational diseases [10].

Applying this method for the same type of job evaluated, at the same time for the same point of work, two evaluators, independent of each other in the end obtain significantly equal results.

This aspect indicates that the method is much more accurate than many of the methods used worldwide to assess the risks of high complexity, where the HOME-MACHINE binomial is seen in a system of structural connections and dependent on the environment in which this binomial is located [11].

\section{Conclusion}

In order to determine the risk, a methodical tool for quantifying the risk indicators was developed, in order to make the diagnosis and the plausible forecast of the mechanism of occurrence of an undesirable event that may occur in a work system.

The method is extremely flexible allowing its adaptation to any work system and to any organizational structure where the human component is analyzed in the work process.

For the types of jobs for which no specific risk categories and subcategories are provided in the method, the methodology allows the structural development harmonized with the specificity characteristic of the new fields, provided that these newly defined categories and subcategories are specific and as detailed as possible.

For the risk situations analyzed in these new areas, the existing weighting criteria in the methodology are applicable or specific weighting criteria can be pre-established which, once introduced, eliminate as much as possible the evaluation error caused by the specific subjectivity of each evaluator applying this methodology.

\section{References}

1. C.R. Garcia, Safety Science J., 49, 306-314, (2011)

2. B. Kirwan, Safety Science, J., 27, 25-75, (1997)

3. J. Kotus, B. Kostek, Archives of Acoustics J., 33, 435-440, (2008)

4. M.F., D'ovidio, Occupational Medicine (Oxford), J., 62, 223-225, (2012)

5. M., Koulouriotis, Loss Prevention in the Process Industries, J., 21, 596-603, (2008)

6. H.E. Price, Human Factors, J., 27, 33-45, (1985)

7. E. Hollnagel, Reliability of cognition: Foundations of Human Reliability Analysis, (Academic Press, Londra, 1996)

8. V.T. Covello, M.W. Merkhofer, Risk Assessment Methods. Approaches for Assessing Health and Environmental Risks, (Springer, Berlin-Heidelberg-New pringer, BerlinHeidelberg-New York, 1993)

9. S. Pece, Risk assessment in the workplace, (Rubin Publishing House, Romania, 2010)

10. G.D. Vasilescu, Probabilistic calculation methods used in the diagnosis and forecast of industrial risk, (INSEMEX Publishing House, Romania, 2008)

11. G.D. Vasilescu, Unconventional methods of professional risk analysis and assessment, (INSEMEX Publishing House, Romania, 2008) 